\title{
No Place Like Home: Place and Community Identity Among North Country Youth
}

\author{
GENEVIEVE R. COX AND CORINNA JENKINS TUCKER
}

\section{Introduction}

$\Lambda$ place is often identified by its physical landscape such as its farming fields, mountains, lakes, or beaches to which individuals attach personal, cultural, and social meanings. These meanings contribute to a locale having a distinct "place identity." Commonly, individuals will mimic the identity of the place around them and come to think of themselves as a "country person" or a "beach person." Thus, a place identity is often connected to people's perceptions of themselves and who they are. This may be particularly true for adolescents, who are in the process of developing their own identities.

The youth of Coos County in the northernmost county in New Hampshire are growing up in a region that is undergoing change. With abundant natural resources, the economic base and identity of Coos County has long been that of a major producer of wood products, but the continued disappearance of the paper industry has brought economic hardship and significant youth outmigration as youth seek better pathways to occupational stability and success. Although new community development strategies are emerging to take advantage of the natural attractiveness of the area, ${ }^{1}$ there is still uncertainty about whether Coos can become a thriving area once again.

\section{Coos Youth Panel Study}

The panel study of Coos County youth is an ongoing study conducted by the Carsey Institute at the University of New Hampshire. Its goal is to track rural youth, family, well being, employment, and residential trends over time. For this brief, we examine 330 youth who were high school seniors in the spring of 2009. The majority are white (95 percent) and between the ages of 17 and 20 . The sample is 52 percent female, and 67 percent of the youth were born in the area.

\section{Key Findings}

- More than half of Coos high school seniors feel they are a part of their community, and almost two-thirds care about their community.

- Self-esteem is higher among twelfth graders who positively identify with their community.

- Youth in Coos County who positively identify with their community are less likely to feel it is important to leave the area and more likely to believe finishing college is important.

As the youth of Coos approach adulthood, their experience of these economic and social shifts may impact how positively they view and identify with their home communities. Furthermore, the extent to which youth feel positively about their community may be linked to how they currently view themselves and their future plans.

In this brief, we explore how frequently Coos youth positively identify with their community and how these youths' positive identification with their community might be tied to their self-esteem, the importance they attach to living in their hometown, and whether they think it is important to finish college.

Youth who care about and take pride in their community may enjoy a sense of comfort that leads to a more positive outlook about themselves, the area, and their academic goals. Thus, despite Coos' shifting identity and economic vulnerability, Coos youths who positively identify with their communities may want to stay in their hometowns rather than migrate. Therefore, we anticipate that Coos youths' positive sense of self and decisions to stay or leave the area and to finish college are likely to be related to whether they positively identify with living in their communities. 


\section{Youth Positive Community Identity}

The experiences youth have in their community, such as participating in community events or social and athletic activities, influence how they view their community. Often, these experiences foster emotional ties to friends and community organizations and can lead individuals to "identify with" a place because of the positive feelings or sense of belonging they develop. ${ }^{2}$ In the last year, 54 percent of Coos County high school seniors surveyed participated in community events.

Studies have shown that rural youth view their communities as inclusive and caring, and the youth in Coos County by and large share this positive view. ${ }^{3}$ Almost 67 percent of high school seniors surveyed said they care about their community; 57 percent feel like part of their community; 59 percent said they are proud to present their community to people; and 57 percent agree they are happy to participate in community events.

\section{Figure 1. Positive Community Identity}

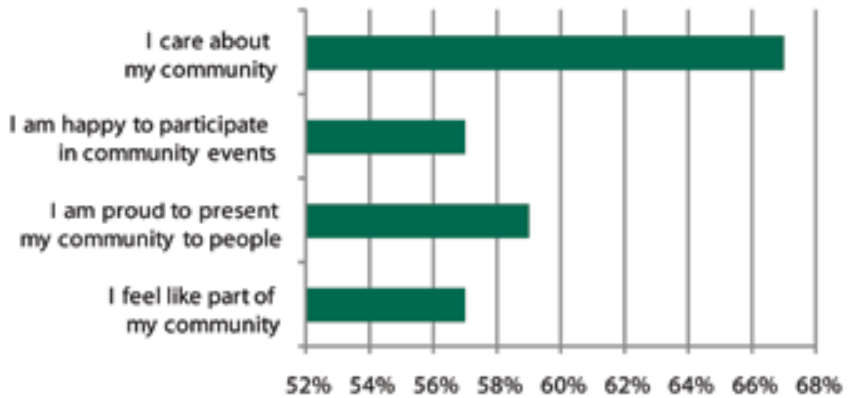

We combined these four variables to create a summary score to get an overall sense of how youth identify with their community. This "positive identity scale" ranges from 0 to 12 , with higher scores indicating more positive identification with the community. ${ }^{4}$ For ease of presentation, we grouped the youth into three categories. About 16 percent of the seniors were in the "low positive" community group (scores 0 to 3 on the scale), and about 42 percent fell within both the moderate (scores from 4 to 7 ) and high (scores from 8 to 12) groups. Then, we used these categories to assess the links between youths' positive identification with their community and their perceptions of themselves and their future residential and academic plans.
Figure 2. Share of Students Scoring Low, Moderate, or High in Positive Community Identity

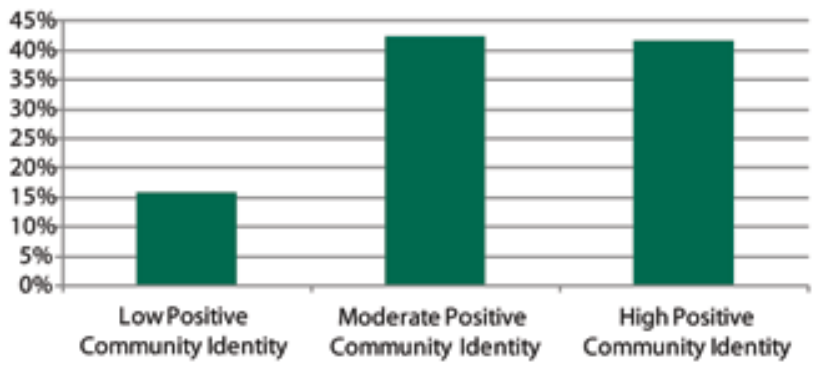

\section{Community Identity and Self-Esteem}

Our analysis of how youths' identification with their community is linked to their self-esteem revealed that youth with the highest positive community identify reported higher self-esteem than do those in the low or moderate positive community identity groups. (The self-esteem scale ranges from 0 to 3 , with higher scores indicating higher self-esteem. ${ }^{5}$ )

Figure 3. Self-Esteem And Positive Community IDENTITY

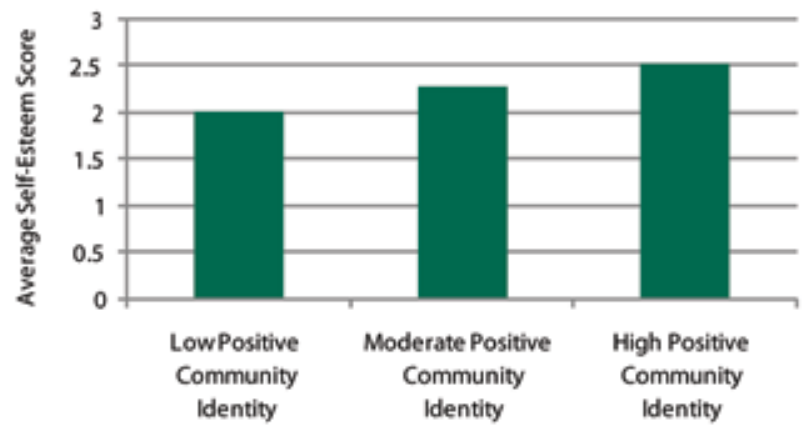

\section{Youth Community Identity and} Future Plans

Even within the context of local economic and social shifts in the North Country, youth with the highest positive identification with their community are less likely to rate leaving the area after high school as important to them and more likely to believe living in their hometown is important. Additionally, youth who report the highest level of positive community identity are more likely to rate finishing college as important. ${ }^{6}$ These findings suggest that even though many youth are choosing to migrate, youths' positive view of their community could lead them to finish college and return to their home communities. 
Figure 4. Future Plans and Positive Community IDENTITY

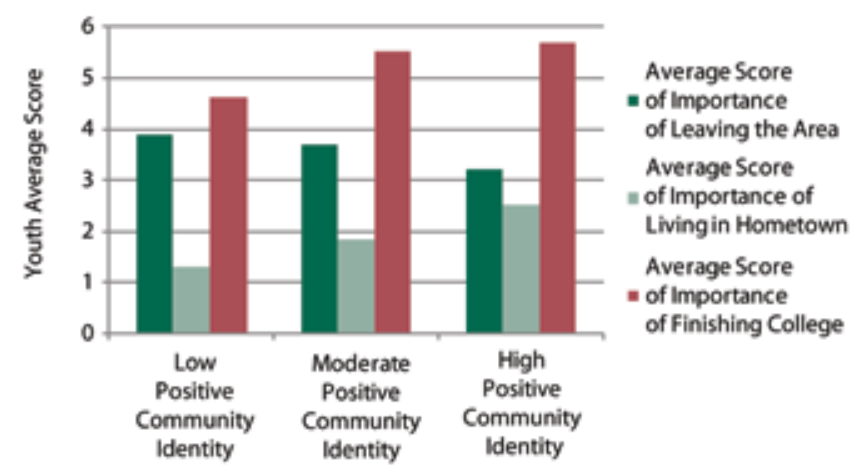

\section{Conclusion}

Places can help create a sense of home, where people feel like they can really "be themselves" and where the questions of "Who am I?" can be partially answered. ${ }^{7}$ Place identity may be influential in how individuals think of themselves and their futures, particularly for youth in the process of forming an identity.

The high school seniors surveyed in the panel study of Coos County youth represent an interesting snapshot into early life transitions and community identification as they solidify their own personal identities and make plans about their future. Given the economic and social shifts currently underway in the North Country and the outmigration of youth in search of opportunities, a positive community identity may be especially important to keep youth in Coos.

The findings of this study show that there are links between rural youths' identification with their community, their self-esteem, and their future plans. Youth who identify more positively with a place have higher self-esteem, are more likely to want to live in the area they grow up in, and more likely to think finishing college is important.

A strong sense of place characterized by a positive community identity could lead more youth to successfully complete their academic goals and consequently invest in their home communities later in life, creating stronger communities in the North Country.

The transition between adolescence and adulthood is often a time when identification with place and community changes. For adults, attachment to community and place tends to increase with age, perhaps owing to less mobility and more time to form local ties. ${ }^{8}$ Future work should explore the pattern of positive community identification during the transition to adulthood. Although our analysis cannot prove that a positive community identity causes higher self-esteem for youth, community identity and self-esteem are associated with one another. Community programs or activities for youth that create social ties might help rural youth form a positive identification with the place they live in and consequently improve their self-esteem and the likelihood for staying or returning to their communities in later adulthood.

\section{EN D N O TES}

1. Chris Colocousis, "The State of Coos County: Local Perspectives on Community and Change," Issue Brief No. 7 (Durham, NH: Carsey Institute, University of New Hampshire, 2008).

2. Gillian Rose, "Place and Identity: A Sense of Place," $A$ Place in the World? Places, Cultures and Globalization, edited by D. Massey and P. Jess (New York: Oxford University Press, 1995): 87-132.

3. Anthony Glendinning et al., "Rural Communities and Well-Being: A Good Place to Grow Up?" Sociological Review, 51 (2003): 129-156.

4. Seniors responded to the statements, "I feel like part of my community," "I am proud to present my community to people," "I am happy to participate in community events," and "I care about my community." The answers range from strongly disagree (0) to strongly agree (3). All answers were combined to form the "positive community identity scale" ranging from 0-12. A factor analysis with varimax rotation indicated one underlying factor for this scale. The alpha reliability coefficient was .89 .

5. We used four items [adapted from Rosenberg's Conceiving the Self (1979)] to measure self-esteem: "I have a number of good qualities," "I am able to do things as well as most people," "I take a positive attitude about myself," and "On the whole, I am satisfied with myself." The scale ranged from 0 (strongly disagree) to 3 (strongly agree). Alpha was .82. A one-way ANOVA indicated significant differences in selfesteem across the three levels of positive community identity $(F=17.20, d f 2 / 319, p<.001)$. The highest level of selfesteem was reported in the high positive community identity group $(M=2.53, S D=.48)$, followed by the moderate positive community identity group $(M=2.27, S D=.60)$ and the low positive community identity group $(M=2.01, S D=.70)$. However, a Barlett's chi-square $(11.70, p<.01)$ indicated that ANOVA's assumption of equal variance is violated. We therefore also ran a Kruskal-Wallis test, and the results $(p<.001)$ indicated a significant difference in the median self-esteem scores across all levels of positive community identity.

6. One-way ANOVAs showed significant differences in high school seniors' rating of the importance of leaving the area $(F=4.24, d f 2 / 324, p=.02)$, importance of living in the town they grew up in $(F=12.38, d f 2 / 324, p<.001)$, and importance of finishing college $(F=14.11, d f 2 / 324, p<$ 


\section{CARSEY INSTITUTE}

.001). Those seniors in the high positive community identity group averaged 3.20 on importance of leaving the area, 2.50 on importance of living in the town in which they grew up, and 5.68 on importance of finishing college. Those seniors in the moderate positive community identity group averaged 3.70 on importance of leaving the area, 1.83 on importance of living in their hometown, and 5.53 on importance of finishing college. Those seniors in the low positive community identity group averaged 3.90 on the importance of leaving the area, 1.30 on importance of living in their hometown, and 4.62 on importance of finishing college.

7. Lee Cuba and David Hummon, "A Place to Call Home: Identification with Dwelling, Community, and Region," The Sociological Quarterly, 34 (1993): 111-131.

8. Robert Sampson, "Local Friendship Ties and Community Attachment in Mass Society: A Multilevel Systemic Model," American Sociological Review, 53 (1988): 766-779.

\section{A C K N O W LE D G M E N T S}

The Coos Youth Study Team is supported by the Neil and Louise Tillotson Fund of the New Hampshire Charitable Foundation and the Carsey Institute. The Coos Youth Study Team thanks the students who are participating in this research project and the superintendents, principals, guidance counselors, teachers, and administrators who helped the team collect these data. Thank you to anonymous reviewers for providing feedback on early drafts of this brief and Amy Sterndale and Laurel Lloyd Earnshaw for editorial assistance. And also special thanks to fellow members of the Coos Youth Research Team, including Cesar Rebellon, Erin Hiley Sharp, Nena Stracuzzi, and Karen Van Gundy.

\section{ABOUT THE AUTHORS}

Genevieve R. Cox, M.A., is a PhD Candidate in the Department of Sociology and a Community, Health, and Environment Fellow with the Carsey Institute at the University of New Hampshire (genevieve.cox@unh.edu).

Corinna Jenkins Tucker, Ph.D., C.F.L.E., is a Carsey Institute faculty fellow and an associate professor in the Department of Family Studies at the University of New Hampshire (cjtucker@unh.edu).

\section{ANIVERSITY}

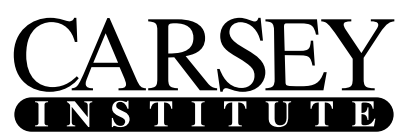

Building knowledge for families and communities

The Carsey Institute conducts policy research on vulnerable children, youth, and families and on sustainable community development. We give policy makers and practitioners timely, independent resources to effect change in their communities.

Carsey Institute Reports on Tracking Change in the North Country are supported by the Neil and Louise Tillotson Fund at the New Hampshire Charitable Foundation and the Carsey Institute endowment.

Huddleston Hall

73 Main Street

Durham, NH 03824

(603) 862-2821

www.carseyinstitute.unh.edu 